\section{Azadirachtin: Potential Use for Controlling Lepidopterous Insects and Increasing Marketability of Cabbage}

\author{
Daniel I. Leskovar and A. Kipp Boales \\ Texas Agricultural Experiment Station, Texas A\&M University, 1619 Garner \\ Field Road, Uvalde, TX 78801 \\ Additional index words. Brassica oleracea, Plutella xylostella, Trichoplusia ni, cabbage \\ looper, diamondback moth, neem, silverleaf whitefly
}

\begin{abstract}
Azadirachtin (ATI), an insect growth regulator derived from extracts of neem (Azadirachta indica A. Juss) seed, was evaluated for the control of cabbage looper (Trichoplusia ni Hübner), diamondback moth (Plutella xylostella L.), and silverleaf whitefly (Bemisia argentifolii Bellows and Perring) in cabbage (Brassica oleracea $\mathbf{L}$. Capitata Group) grown in southwestern Texas. In Fall 1992, ATI was tested with the a.i. at $0,22,33$ and $44 \mathrm{~g} \cdot \mathrm{ha}^{-1}$. In 1993, ATI was evaluated at $33 \mathrm{~g} \cdot \mathrm{ha}^{-1}$ and in combination with M-Pede $(1 \%, v / v)$, an organic insecticide based on potassium salts of fatty acids at $49 \%$. Two commercial (Align and Neemix) and one experimental hydrogenated (LDF) ATI formulations were evaluated at $11 \mathrm{~g} \cdot \mathrm{ha}^{-1}$ in 1994 . Insect populations were monitored weekly before and after treatment application. Plant damage was evaluated immediately before harvest, and marketable yields were determined. In 1992, large ( $>6 \mathrm{~mm}$ long) and total cabbage looper counts were reduced by ATI compared with the nontreated control.

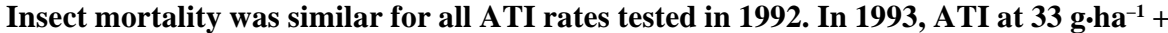
M-Pede reduced the number of cabbage looper and diamondback moth larvae. ATI efficacy against cabbage looper and diamondback moth was enhanced when crop oil (polyol fatty acid esters with polyethoxylated derivatives) was tank-mixed with Align or LDF formulations in 1994. ATI did not reduce the number of silverleaf whitefly nymphs compared to the control. In all seasons, A TI-treated plants had lower insect-induced plant damage and higher marketable head weights than the nontreated control. Using ATI on lepidopterous pests appears to be beneficial for integrated pest management strategies.
\end{abstract}

Cabbage is a regular component of crop rotation systems in southwestern Texas, with $\approx 2400$ ha grown in the $1994-95$ season. The mild climate in this region allows multi-crop cabbage production for 8 months. These production conditions ensure the continuous survival and reproduction of damaging insect pests. Cabbage looper (CL), diamondback moth (DBM), and silverleaf whitefly (SLWF) (formerly the sweetpotato whitefly $B$. tabaci Gennadius) are the major economically important insect pests in cabbage.

Control of cabbage pests generally has been achieved with broad-spectrum synthetic insecticides. Potential problems associated

Received for publication 20 Oct. 1995. Accepted for publication 6 Feb. 1996. We thank AgriDyne Technologies, Salt Lake City, (in Mar. 1996 AgriDyne became subsidiary of biosys, Columbia, Md.) for financial support of this research and J.W. Stewart, professor and extension entomologist, Texas Agricultural Extension Service, Uvalde; W. Ruggero, AgriDyne Technologies; and R. Sprague, R.J. Santos, and J.C. Ward, Texas Agricultural Expt. Station, Uvalde, for their inputs and technical assistance in the experiments. Mention of a trademark, proprietary product, or vendor does not constitute a guarantee or warranty of the product nor does it imply approval or disapproval to the exclusion of other products or vendors that may also be suitable. The cost of publishing this paper was defrayed in part by the payment of page charges. Under postal regulations, this paper therefore must be hereby marked advertisement solely to indicate this fact. with continued long-term use of these insecticides include pest resistance and a negative impact on nontarget organisms. In recent years, research has focused on selective natural insecticides originating from plants (Ascher, 1993). Azadirachtin (ATI), a tetranortriterpenoid derived from extracts of neem seeds and isolated by Butterworth and Morgan (1968), is an insect growth regulator. When Vertical bars are means $\pm \mathrm{SE}$. ingested or absorbed by insect larvae, ATI affects the molting process [Mordue (Luntz) and Blackwell, 1993; Rembold, 1989; Schmutterer, 1990], preventing the insect larvae from developing into adults. ATI acts on young larvae and generally does not affect adults or eggs, unlike insecticides in such chemical classes as pyrethroids, carbamates, or organophosphates. ATI either does not affect or has minor side effects on important beneficial organisms (Kaethner, 1991; Schmutterer, 1990).

Previous efficacy data using commercial and experimental neem preparations were derived from laboratory and greenhouse studies [Mordue (Luntz) and Blackwell, 1993]. To develop an effective integrated pest management (IPM) program in cabbage, field comparisons of ATI efficacy against lepidopterous and other phytophagous insects are needed. Our goal was to evaluate the effectiveness of ATI formulations for the control of CL, DBM, and SLWF and subsequent marketable yields in cabbage.

\section{Materials and Methods}

Fall 1992. 'Green Cup' cabbage was direct-seeded with a cone planter on a Uvalde silty clay loam (fine-silty, mixed, hyperthermic Aridic Calciustoll) soil at the Texas Agricultural Expt. Station (TAES), Uvalde, on 16 Sept. 1992. Plants were grown on single raised (15 $\mathrm{cm}$ high) beds with $1.0-\mathrm{m}$ between-row and $0.3-\mathrm{m}$ within-row spacing. Each plot consisted of five 8-m-long beds, three from which data were taken and two buffer rows. A randomized complete-block design with four replications was used. A preplant fertilizer blend (N, P, and $\mathrm{K}$ at $50 \mathrm{~kg} \cdot \mathrm{ha}^{-1}$ each) was broadcasted and incorporated.

In ATI treatments, the a.i. was at 22, 33, or $44 \mathrm{~g} \cdot \mathrm{ha}^{-1}$. A commercial formulation (Align, with azadirachtin, a.i. 3\%; AgriDyne, Salt Lake City) was the source of ATI. A control (water) also was included. Treatments were

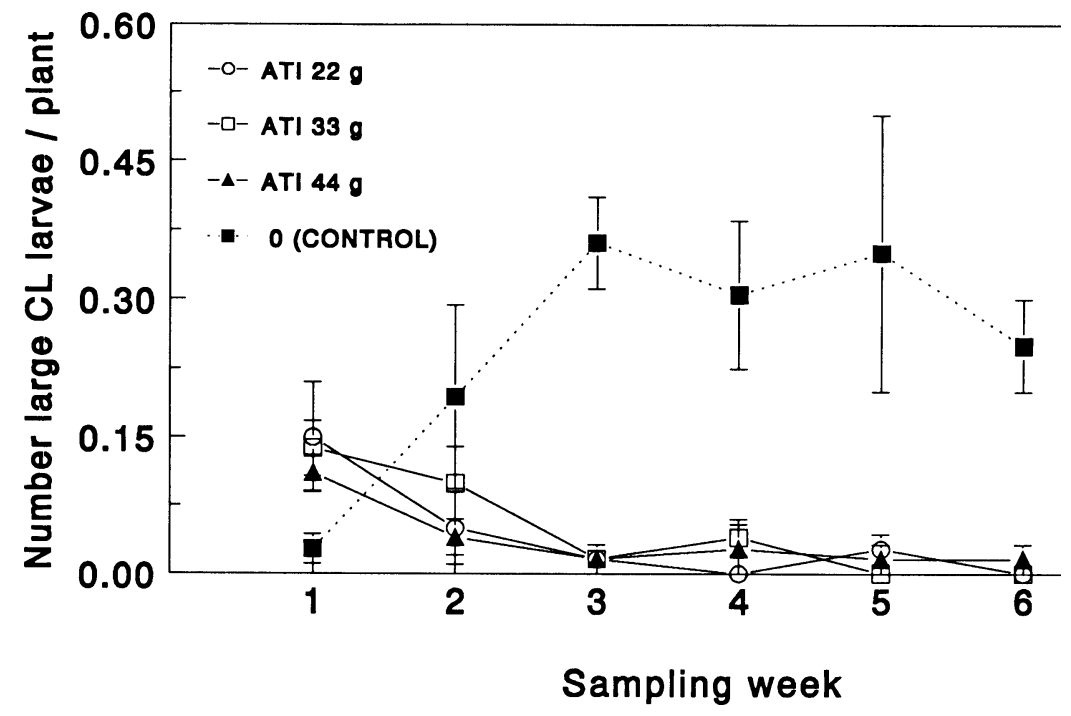

Fig. 1. Number of large ( $>6 \mathrm{~mm}$ long) cabbage looper (CL) (Trichoplusia ni) larvae per plant as affected by azadirachtin (ATI) concentrations (grams of a.i. per hectare) on cabbage in Uvalde, Texas, Fall 1992. 
applied on 29 Oct. and 5, 12, 19, and 26 Nov. using 500 liters $\cdot \mathrm{ha}^{-1}$. $\mathrm{A} \mathrm{CO}_{2}$ sprayer (Weed Systems Equipment, Keystone Heights, Fla.) with an inverted-U design and three nozzles per row of cabbage was used at $350 \mathrm{kPa}$. Induce $\mathrm{pH}$ (Setre Chemical Co., Memphis) was added at 5 ml.liter ${ }^{-1}$.

In Fall 1992, CL was the only lepidopterous pest observed. CL counts were made on 18 plants per plot ( 72 plants per treatment) on 27 Oct. (pretreatment); 4, 11, 19, and 25 Nov.; and 2 Dec. (the first through the fifth posttreatment dates). Larvae were grouped by size into small ( $\leq 6 \mathrm{~mm}$ long) or large $(>6 \mathrm{~mm})$. SLWF was monitored by selecting the fourth oldest leaf on 18 plants per plot on 27 Oct. (pretreatment) and 4, 11, and 25 Nov. (the first through the third post-treatment dates). A 100$\mathrm{cm}^{2}$ plastic grid was placed on top of each leaf, ten $1-\mathrm{cm}^{2}$ sites per leaf (total $720 \mathrm{~cm}^{2} /$ treatment) were selected, and nymphs were counted using a stereo-microscope at $\times 18$. Nymphs were counted and grouped into first + second instar and third + fourth instar. On 4 Nov., SLWF eggs were counted using the same procedure used for nymph counts.

On 16 Dec., five individuals separately rated insect-induced plant damage before harvest. This damage was rated visually on a scale of 1 to 5 , where $1=$ minimum larvae feeding on outer leaves; 2 = slight damage on wrapper leaves; 3 = moderate damage on outer and wrapper leaves; $4=$ damage on rosette, wrapper, and outer leaves; and $5=$ head seriously damaged. Twenty cabbage heads were harvested randomly on 25 Feb. 1993 from three 6$\mathrm{m}$-long rows, and heads were classified as marketable or culls. Insect counts and cabbage yield were subjected to analysis of variance, and treatment effects were partitioned using the orthogonal contrast procedure.

Fall 1993. 'Pennant' cabbage was directseeded at the TAES on 8 Sept. 1993. Procedures similar to Fall 1992 procedures were followed, except that only ATI at $33 \mathrm{~g} \cdot \mathrm{ha}^{-1}$ was used. M-Pede (Mycogen Corp., San Diego), an insecticide based on potassium salts of fatty acids at $49 \%$, also was used at $1 \%(\mathrm{v} / \mathrm{v})$ in combination with ATI. Treatments were ATI, ATI + M-Pede, M-Pede 1\%, and control (water). All were buffered with Induce $\mathrm{pH}$ at 5 $\mathrm{ml} \cdot$ liter $^{-1}$. They were applied on 20 and 26 Oct. and 2 and 10 Nov. Three additional sprays were applied on 10 Dec. and 4 and 12 Jan. 1994. All procedures, including cultural practices, design, and treatment application were similar to the 1992 test.

CL larvae, DBM larvae, and SLWF nymph counts were made on 15 plants per plot on 19 (pretreatment) and 25 Oct. and 1, 8, and 15 Nov. (the first through the fourth posttreatment dates). Sampling for SLWF was performed by selecting 10 leaves per experimental unit. Nymphs were counted on a total of $10 \mathrm{~cm}^{2}$ per leaf $\left(400 \mathrm{~cm}^{2} /\right.$ treatment $)$ as previously described. Plant damage resulting from insect feeding was rated on $7 \mathrm{Feb}$. as previously described, and cabbage heads were harvested on 11 Feb. 1994.

Fall 1994. 'Pennant' cabbage transplants were planted on 2 Sept. 1994 . To determine the efficacy of a lower rate than that used in the 1992 and 1993 experiments, ATI was evaluated at $11 \mathrm{~g} \cdot \mathrm{ha}^{-1}$ using three formulations: Align (similar as in 1992 and 1993, and herein referred to as ATI), LDF (experimental formulation, AgriDyne), and Neemix (W.R. Grace \& Co., Columbia, Md.) at either weekly or biweekly spray intervals. Treatments were 1)

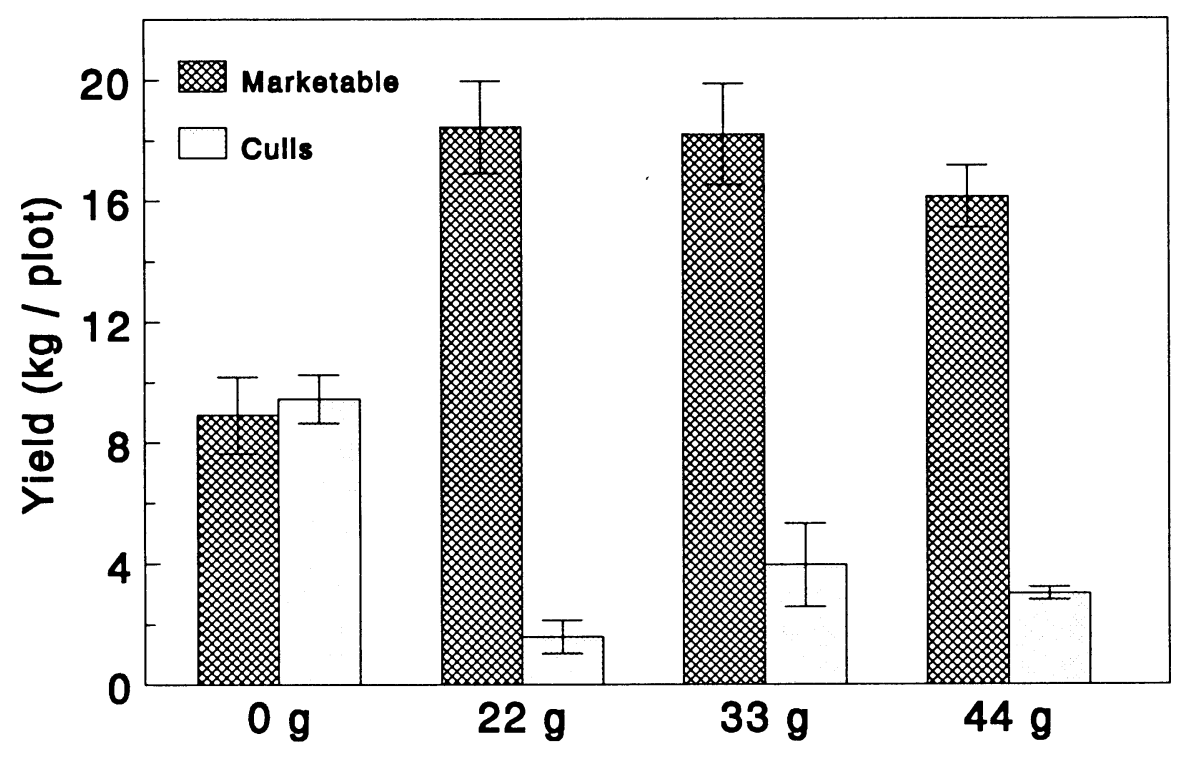

\section{ATI a.i./ha}

Fig. 2. Cabbage yield as affected by azadirachtin (ATI) concentrations (grams of a.i. per hectare) in Uvalde, Texas, Fall 1992. Vertical bars are means \pm SE.

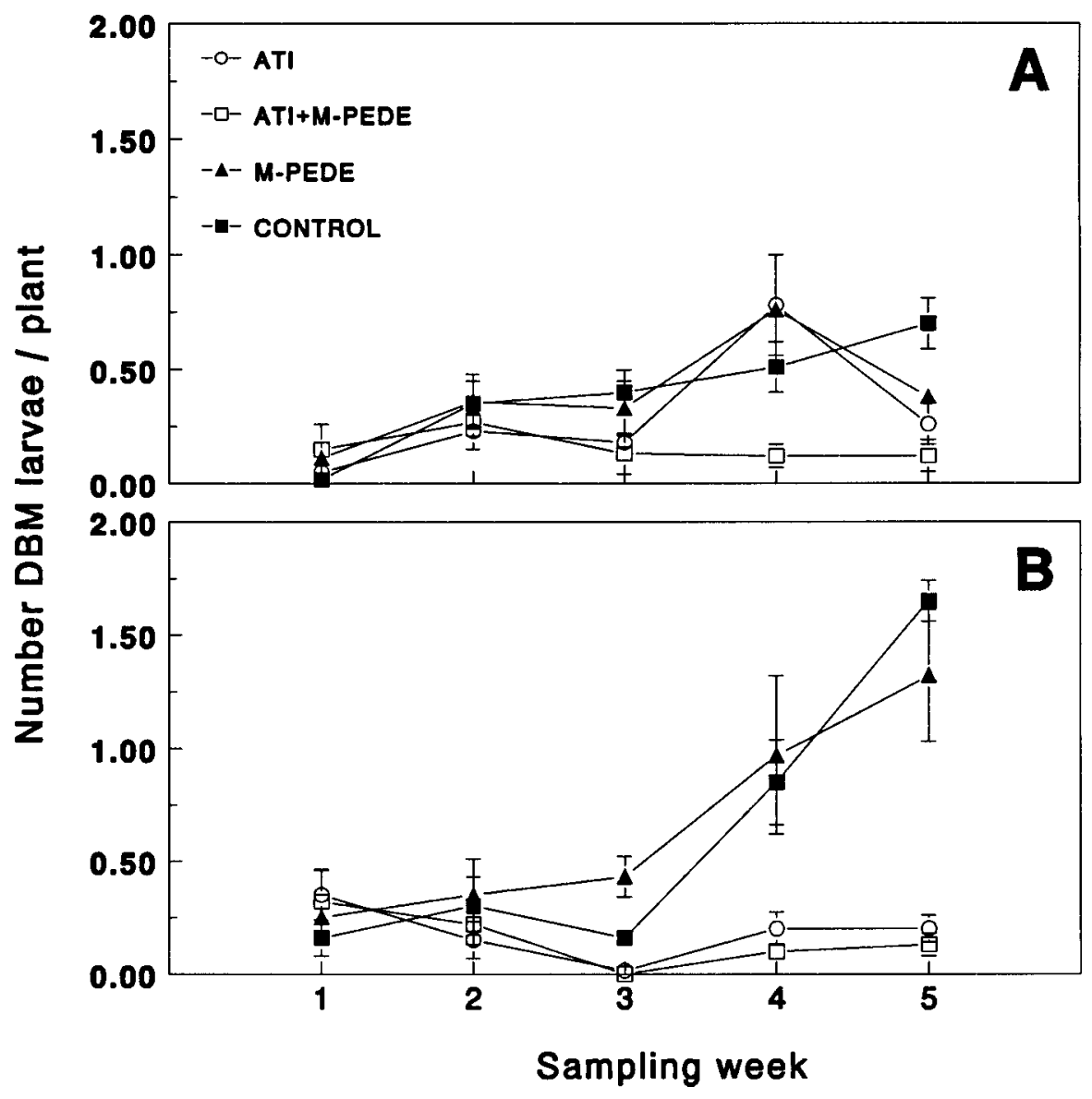

Fig. 3. Number of (A) small ( $\leq 3 \mathrm{~mm}$ long) and (B) large $(>3 \mathrm{~mm})$ diamondback moth (DBM) (Plutella xylostella) larvae per plant as affected by azadirachtin (ATI) applied with the a.i. at $33 \mathrm{~g}^{\circ} \mathrm{ha}^{-1}$ and M-Pede at $1 \%(\mathrm{v} / \mathrm{v})$ on cabbage in Uvalde, Texas, Fall 1993. Vertical bars are means \pm SE. 
ATI weekly, 2) ATI + oil (a nonionic spray adjuvant $99 \%$ polyol fatty acid esters and polyethoxylated derivatives; Setre Chemical Co.) at $0.5 \%(\mathrm{v} / \mathrm{v})$ weekly, 3) LDF weekly, 4) LDF + oil weekly, 5) ATI biweekly, 6) ATI + oil biweekly, 7) LDF biweekly, 8) LDF + oil biweekly, 9) oil weekly, 10) oil biweekly, 11) Neemix with no oil weekly, 12) Neemix with no oil biweekly, and 13) control (water).

Applications were made on 29 Sept. and 6, 13 , and 20 Oct. $(27,34,41$, and 48 days after transplanting, respectively). Additional biweekly sprays were applied on 29 Sept. and 13 Oct. Treatments were sprayed as in the Fall 1992 experiment, except that the $\mathrm{CO}_{2}$ sprayer pressure was $414 \mathrm{kPa}$. To maintain a $\mathrm{pH}$ at $\approx 6.7$, a nonionic surfactant-acidifier $(80 \%$ phosphatidylcholine, methylacetic acid, and alkyl polyoxyehtylene ether; Loveland Industries, Greeley, Colo.) was added at $0.5 \mathrm{ml} \cdot \mathrm{liter}^{-1}$.

CL and DBM counts were made on 12 plants per plot (48 plants per treatment) on 28 Sept. (pretreatment) and 5, 12, 19, and 26 Oct. (the first through the fourth post-treatment dates). Sampling for SLWF was performed by selecting 10 leaves per experimental unit on 28 Sept. and 13 and 28 Oct. Nymphs were counted on a total of $10 \mathrm{~cm}^{2} /$ leaf $\left(400 \mathrm{~cm}^{2} /\right.$ treatment $)$ as previously described. Insect-induced plant damage before harvest was rated on 11 Nov., and cabbage heads were harvested on 30 Nov. 1994. The design was similar to that in 1992. The following orthogonal contrasts were used to compare treatments: ATI vs. control, LDF vs. control, oil vs. control, Neemix vs. control, ATI vs. LDF, ATI weekly vs. ATI biweekly, LDF weekly vs. LDF biweekly, oil weekly vs. oil biweekly, ATI vs. ATI + oil, LDF vs. LDF + oil, ATI vs. Neemix, and LDF vs. Neemix. Where treatment $\times$ time interactions were significant, means at each sampling time were

Table 1. Effects of azadirachtin (ATI) with a.i. at 33 $\mathrm{g} \cdot \mathrm{ha}^{-1}, \mathrm{M}$-Pede $(1 \% \mathrm{v} / \mathrm{v})$, and ATI + M-Pede on the control of cabbage looper (Trichoplusia ni) on cabbage in Uvalde, Texas, Fall 1993.

\begin{tabular}{|c|c|c|c|}
\hline \multirow{2}{*}{$\begin{array}{l}\text { Source of } \\
\text { variation }\end{array}$} & \multicolumn{3}{|c|}{$\begin{array}{l}\text { Cabbage loopers larvae } \\
\text { (no./plant) }^{z}\end{array}$} \\
\hline & Small & Large & Total \\
\hline \multicolumn{4}{|l|}{ Treatment (Trt) } \\
\hline ATI & 0.65 & 0.21 & 0.86 \\
\hline ATI + M-Pede & 0.62 & 0.07 & 0.69 \\
\hline M-Pede & 0.73 & 0.5 & 1.23 \\
\hline Control & 0.69 & 0.35 & 1.03 \\
\hline $\mathrm{LSD}_{0.05}$ & NS & 0.16 & 0.29 \\
\hline \multicolumn{4}{|l|}{ Time (week) ${ }^{y}$} \\
\hline 1 & 0.7 & 0.26 & 0.97 \\
\hline 2 & 1.34 & 0.36 & 1.7 \\
\hline 3 & 0.51 & 0.23 & 0.73 \\
\hline 4 & 0.49 & 0.3 & 0.79 \\
\hline 5 & 0.32 & 0.26 & 0.57 \\
\hline Significance & NS & NS & $\mathrm{L}^{* *}, \mathrm{Q}^{*}$ \\
\hline Trt $\times$ time & NS & NS & NS \\
\hline \multicolumn{4}{|c|}{$\begin{array}{l}{ }^{2} \text { Data are means of } 60 \text { plants per treatment }(15 \text { plants } \\
\text { per replication); small, } \leq 6 \mathrm{~mm} \text { long; large, }>6 \mathrm{~mm} \text {. } \\
\text { y Time means are averaged across all treatments. } \\
\text { Time } 1=19 \text { Oct. (pretreatment count) and times } 2 \text { to } \\
5=26 \text { Oct. through } 15 \text { Nov. (first to fourth post- } \\
\text { treatment counts). } \\
\text { ws, }{ }^{* * *} \text { Nonsignificant or significant } F \text { test at } P \leq 0.05 \\
\text { or } 0.01 \text {, respectively. Time effects were linear (L) or } \\
\text { quadratic (Q). }\end{array}$} \\
\hline
\end{tabular}

separated by least significant difference at $P \leq$ 0.05 .

\section{Results and Discussion}

Fall 1992. Phytotoxicity or deleterious plant growth effects were absent. The number of large CL larvae was reduced by all ATI treatments after the second ATI application, with $\leq 96 \%$ mortality in relation to the control (Fig. 1). Similarly, total (small + large) CL larva counts were significantly reduced by all ATI treatments compared with the nontreated control (not shown). This season was characterized by a low worm complex pressure. The total number of lepidopterous insects for ATItreated plants never exceeded the action threshold of 0.3 larvae per plant established by

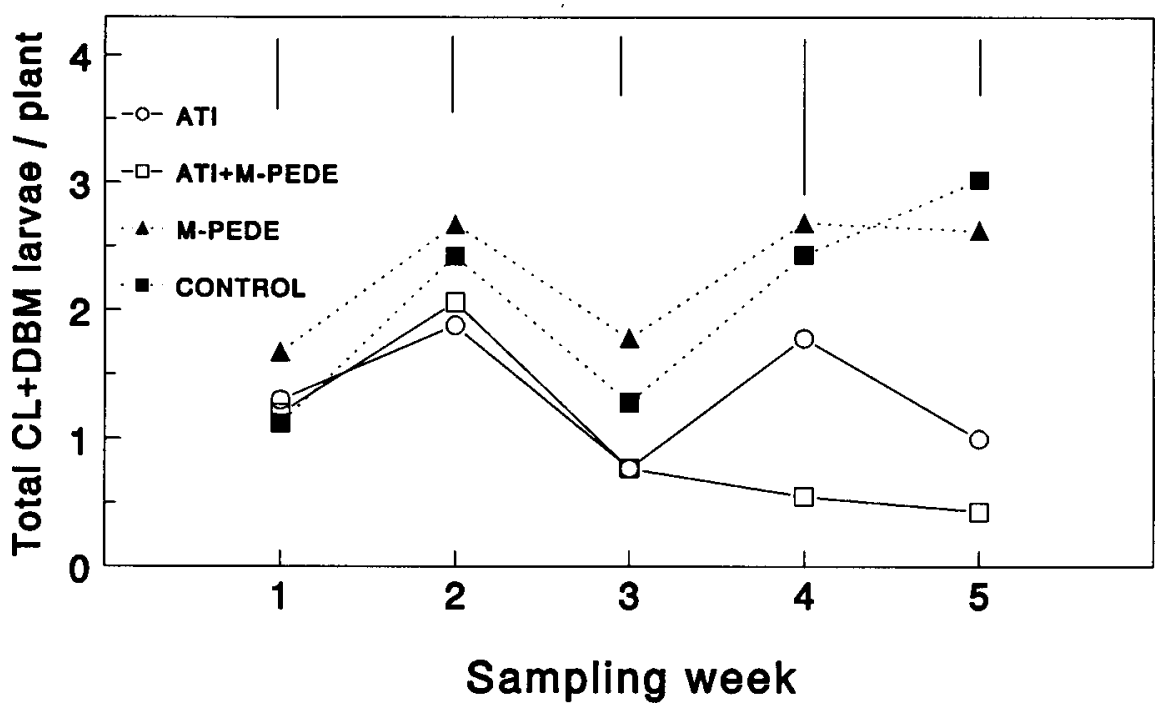

Fig. 4. Total number of lepidopterous [cabbage looper (CL) (Trichoplusia ni) + diamondback moth (DBM)

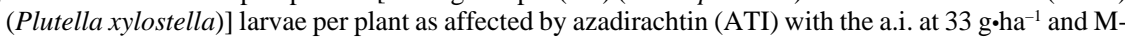
Pede at $1 \%(\mathrm{v} / \mathrm{v})$ on cabbage in Uvalde, Texas, Fall 1993. Vertical bars represent least significant difference at $P \leq 0.05$.

Table 2. Effects of azadirachtin [ATI = Align, LDF (experimental formulation), and Neemix] with the a.i. at $11 \mathrm{~g} \cdot h \mathrm{a}^{-1}$ and oil at $(0.5 \%)$ on the control of diamondback moth (DBM) (Plutella xylostelia) and cabbage looper (Trichoplusia ni) on cabbage in Uvalde, Texas, Fall 1994. ${ }^{\mathrm{z}}$

\begin{tabular}{|c|c|c|c|c|c|c|}
\hline \multirow[b]{2}{*}{ Treatment } & \multirow{2}{*}{$\begin{array}{l}\text { Spray interval } \\
\text { (days) }\end{array}$} & \multirow{2}{*}{$\begin{array}{l}\text { DBM } \\
\text { small }\end{array}$} & \multicolumn{4}{|c|}{ Cabbage looper no./plant } \\
\hline & & & Small & Large & Pupae & Total \\
\hline ATI & 7 & 0.73 & 1.21 & 1.08 & 0.08 & 2.37 \\
\hline $\mathrm{ATI}+$ oil & 7 & 0.65 & 1.17 & 0.38 & 0.03 & 1.57 \\
\hline LDF & 7 & 0.73 & 1.13 & 1.05 & 0.06 & 2.24 \\
\hline $\mathrm{LDF}+$ oil & 7 & 0.64 & 1.09 & 0.58 & 0.02 & 1.69 \\
\hline ATI & 14 & 0.98 & 1.22 & 0.87 & 0.05 & 2.14 \\
\hline $\mathrm{ATI}+$ oil & 14 & 0.87 & 1.28 & 0.53 & 0.02 & 1.84 \\
\hline LDF & 14 & 0.92 & 1.13 & 1.08 & 0.06 & 2.28 \\
\hline $\mathrm{LDF}+$ oil & 14 & 0.66 & 1.00 & 0.61 & 0.01 & 1.63 \\
\hline \multirow[t]{2}{*}{ Oil } & 7 & 0.96 & 1.03 & 0.87 & 0.06 & 1.96 \\
\hline & 14 & 0.73 & 1.03 & 0.74 & 0.06 & 1.84 \\
\hline \multirow[t]{2}{*}{ Neemix } & 7 & 1.03 & 1.13 & 0.96 & 0.05 & 2.15 \\
\hline & 14 & 1.07 & 1.09 & 1.31 & 0.09 & 2.49 \\
\hline Control & 7 & 1.41 & 1.53 & 1.30 & 0.21 & 3.04 \\
\hline \multicolumn{7}{|l|}{ Orthogonal contrasts $y$} \\
\hline ATI vs. control & & 0.01 & 0.09 & 0.01 & 0.00 & 0.00 \\
\hline LDF vs. control & & 0.00 & 0.03 & 0.06 & 0.00 & 0.00 \\
\hline Oil vs. control & & 0.01 & 0.00 & 0.00 & 0.00 & 0.00 \\
\hline Neemix vs. control & & 0.10 & 0.02 & 0.20 & 0.00 & 0.00 \\
\hline ATI vs. LDF & & 0.58 & 0.23 & 0.12 & 0.71 & 0.87 \\
\hline \multicolumn{7}{|l|}{ ATI weekly vs. } \\
\hline ATI biweekly & & 0.19 & 0.67 & 0.76 & 0.54 & 0.93 \\
\hline \multicolumn{7}{|l|}{ LDF weekly vs. } \\
\hline LDF biweekly & & 0.56 & 0.78 & 0.78 & 0.93 & 0.93 \\
\hline $\begin{array}{l}\text { Oil weekly vs. } \\
\text { oil biweekly }\end{array}$ & & 0.37 & 1.00 & 0.40 & 0.99 & 0.64 \\
\hline ATI vs. ATI + oil & & 0.59 & 0.94 & 0.00 & 0.13 & 0.00 \\
\hline LDF vs. LDF + oil & & 0.35 & 0.57 & 0.00 & 0.15 & 0.00 \\
\hline ATI vs. Neemix & & 0.29 & 0.51 & 0.11 & 0.93 & 0.72 \\
\hline LDF vs. Neemix & & 0.22 & 0.89 & 0.49 & 0.70 & 0.74 \\
\hline
\end{tabular}

${ }^{2}$ Experiment was planted on 2 Sept. 1994. Means were pooled across all sampling times. Treatments $\times$ time interactions were not significant.

${ }^{y}$ Orthogonal contrast comparisons are significant if $P \leq 0.05$. 
Cartwright et al. (1987). The number of SLWF eggs and first + second and third + fourth nymphal stages was unaffected by ATI (data not shown).

Plant damage evaluation before harvest indicated that the control plants had higher $(P$ $\leq 0.05)$ mean insect damage ratings (mean \pm $\mathrm{SE}, 3.4 \pm 0.1)$ than ATI-treated plants (1.9 \pm $0.1)$. Similarly, control plants had lower marketable head weights and more culls than ATItreated plants (Fig. 2).

Fall 1993. During this season, the worm complex pressure was moderate but higher than in Fall 1992. The number of large and total $\mathrm{CL}$ was reduced by ATI at $33 \mathrm{~g} \cdot \mathrm{ha}^{-1}+\mathrm{M}$-Pede compared with the control; however, no treatment was effective in controlling small CL larvae (Table 1). Since there was a significant treatment $\times$ time interaction for the number of small and large DBM (data not shown), data were partitioned over time (Fig. 3). ATI and ATI + M-Pede significantly reduced the number of small (Fig. 3A) and large (Fig. 3B) DBM larvae at or after the third sampling week. Thereafter, there was a rapid increase of large DBM larvae on the M-Pede-treated and control plots (Fig. 3B), which suggests that, depending on the DBM stage of development, death or delay in the moult may occur within 1 to 2 weeks after contact with ATI. The total number of CL + DBM was significantly reduced by ATI and ATI + M-Pede at the third and fifth week of sampling (Fig. 4). At the fourth sampling week, a time at which there was an unexplained large variability, ATI combined with M-Pede achieved a significant reduction of CL + DBM over that of ATI alone (Fig. 4). No effect of ATI either alone or combined with M-Pede was found on SLWF.

Plants treated with ATI and ATI + M-Pede had a lower average head damage rating (2.2 \pm 0.1 and $1.7 \pm 0.1$, respectively) than M-Pede alone or the nontreated control $(3.8 \pm 0.1)$. Similar to Fall 1992, ATI-treated plots had higher marketable head weights than the control $(22.4 \pm 0.6$ and $14.9 \pm 0.7 \mathrm{~kg}$, respectively).

Fall 1994. The number of small DBM larvae was reduced by ATI, LDF, and oil applied weekly or biweekly compared with the control (Table 2). No synergistic effect on small DBM larvae was measured when oil was added to ATI $(P \leq 0.05)$. ATI formulations (ATI or LDF) and oil alone had similar efficacy on small DBM larvae when applied either weekly or biweekly, while there were no differences in efficacy on small DBM larvae among ATI, LDF, and Neemix $(P \leq 0.22)$.

Significant treatment $\times$ time interactions for the number of large larvae, pupae, and total DBM larvae were partitioned over time (Fig. 5). Since plants treated with ATI biweekly had higher levels of DBM compared to those sprayed weekly, only responses for the weekly ATI sprays are shown. ATI + oil and LDF + oil significantly reduced the number of large DBM larvae (Fig. 5A), indicating that ATI in the presence of oils had an enhanced hormonal action preventing molting. Spray oils have been used widely on several pests and crops (Johnson, 1985). Whether oil enhances ATI
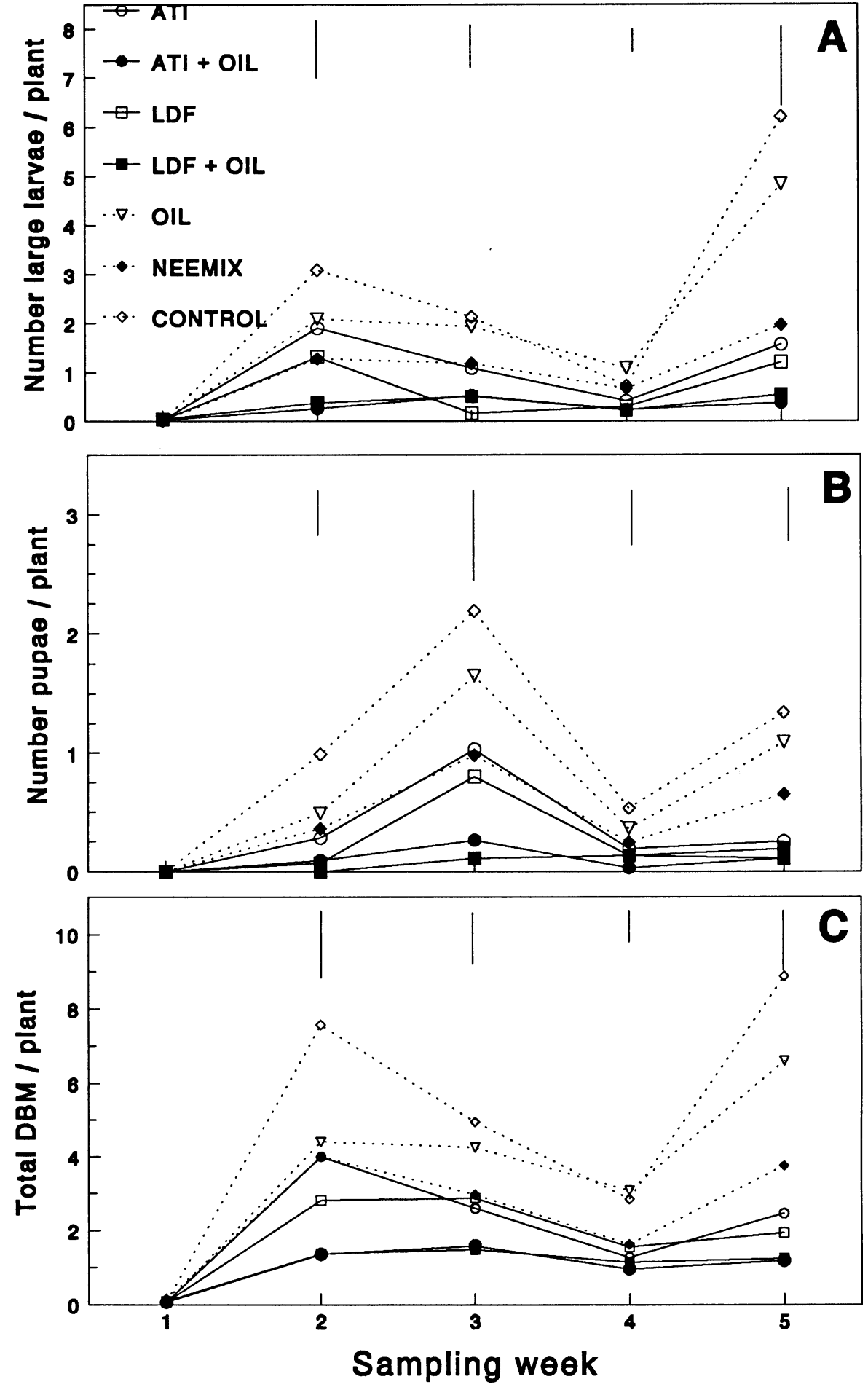

Fig. 5. Number of (A) large larvae ( $\geq 3 \mathrm{~mm}$ long), (B) pupae, and (C) total diamondback moth (DBM) (Plutellaxylostella) per plant as affected by azadirachtin [ATI = Align, LDF (experimental formulation), and Neemix] with the a.i. at $11 \mathrm{~g} \cdot \mathrm{ha}^{-1}$ and oil $(0.5 \%)$ on cabbage in Uvalde, Texas, Fall 1994. Vertical bars represent least significant difference at $P \leq 0.05$.

mode of action, such as an increase of its penetration, or increases its stability has yet to be determined. Stokes and Redfern (1982) reported that incorporating ATI into neem oil gave protection to the ATI molecule. Plants treated with oil alone had the same counts of large DBM larvae as the control. Similar efficacy trends were observed for the number of DBM pupae. In the absence of oil, a significant number of large DBM larvae (Fig. 5A) entered into a pupal stage (Fig. 5B) after the second sampling week. On 18 Sept., 1 day before the fourth sampling week, there was $57 \mathrm{~mm}$ of precipitation. The decline in larva counts for all treatments may have been related to the direct impact of rain as a result of disturbed mating and egg-laying activities, washed off eggs, and decreased survival of DBM through the larval stages. Thereafter, DBM populations increased rapidly, but ATI-, LDF-, and Neemix-treated plants held DBM levels to the pre-rain populations (about four times lower). 
Similarly, the total number of DBM (small + large + pupae) were significantly reduced by ATI and LDF formulations in the presence of oil (Fig. 5C).

LDF, oil, and Neemix significantly reduced $(P \leq 0.02)$ the number of small larvae, pupae, and total CL compared with the control (Table 2). ATI also reduced the number of large, pupa, and total CL but was less effective in controlling small CL larvae $(P=0.09)$. The lack of significant effect of ATI on small CL was consistent with the 1992 and 1993 results. $\mathrm{ATI}+$ oil and LDF + oil decreased the number of large CL larvae. All CL life stages were controlled similarly by ATI, LDF, and Neemix. The two spraying intervals were about equally effective for ATI, LDF, and oil (Table 2).

The number of SLWF first + second and third + fourth nymphal stages were unaffected by ATI (data not shown), except in one case where ATI + oil achieved slightly lower total SLWF nymphs than ATI alone (0.2 vs. 0.1 nymphs $/ \mathrm{cm}^{2}$, respectively).

Plants treated with ATI + oil and LDF + oil had lower insect-induced head damage ratings (data not shown) and higher marketable head weights $(P \leq 0.01)$ than those in the absence of oil (Table 3). Similarly, ATI- and LDF-treated plants had higher marketable yield when applied weekly rather than biweekly. However, the marketability results for Fall 1994 must be taken with caution since in this experiment, the lepidopteran levels before application initiation were higher than the threshold action established by Cartwright et al. (1987). They have determined that when total lepidopterous counts are maintained at $<0.3$ larvae per plant, damage of cabbage heads can be $<1 \%$ of the total number of heads harvested.

Inefficacy of ATI against SLWF activity in the three years may be related to the low ATI rate used in our experiments ( 11 to $44 \mathrm{~g} \cdot \mathrm{ha}^{-1}$ ). Flint and Parks (1989) reported that ATI at 22 g.ha ${ }^{-1}$ was ineffective on immature SLWF on cotton (Gossypium hirsutum L.), but a $60 \%$ reduction occurred at $176 \mathrm{~g} \cdot \mathrm{ha}^{-1}$. Conversely, ATI sprays were effective in controlling SLWF nymph stages when applied at 22 to $44{\mathrm{~g} \cdot h \mathrm{~h}^{-1}}^{-1}$ on poinsettia (Euphorbia pulcherrima Wild.) grown in a greenhouse (Price et al., 1990). Antifeeding activity for Homoptera, Coleoptera, and Hemiptera species was achieved with ATI at 110 to $660 \mathrm{~g} \cdot \mathrm{ha}^{-1}$ compared to $<1$ to $55 \mathrm{~g} \cdot \mathrm{ha}^{-1}$ for Lepidoptera species (Mordue and Blackwell, 1993).

Our experiments have shown the potential of ATI-based insecticides alone and in combination with oil for control of CL and DBM to increase marketability of field-grown cabbage, at least in southwestern Texas. ATI was effective under conditions of low (1992) and high (1994) lepidopterous insect pressure. The control of DBM may be of particular importance because this insect species has demonstrated resistance to broad-spectrum insecticides such as (3-phenoxyphenyl methyl $( \pm)$-cis-trans 3( $2,2-\mathrm{d}$ i c h 1 or oe the n y 1$)-2,2$ dimethylcyclopropanecarboxylate; hexachlorohexahydromethano-2,4,3benzodioxathiepin oxide; methomyl $\{S$-methyl

Table 3. Effects of azadirachtin [ATI = Align, LDF (experimental formula), and Neemix] with the a.i. at 11 $\mathrm{g} \cdot \mathrm{ha}^{-1}$ and oil at $0.5 \%$ on cabbage yields in Uvalde, Texas, Fall $1994 .^{\mathrm{z}}$

\begin{tabular}{|c|c|c|c|}
\hline \multirow[b]{2}{*}{ Treatment } & \multirow{2}{*}{$\begin{array}{c}\text { Spray } \\
\text { interval (days) }\end{array}$} & \multicolumn{2}{|c|}{ Head wt/plot } \\
\hline & & Marketable (kg) & Culls (kg) \\
\hline ATI & 7 & 3.09 & 18.55 \\
\hline ATI + oil & 7 & 15.19 & 10.55 \\
\hline LDF & 7 & 7.32 & 13.76 \\
\hline LDF + oil & 7 & 16.03 & 7.31 \\
\hline ATI & 14 & 1.71 & 18.95 \\
\hline ATI + oil & 14 & 2.63 & 15.10 \\
\hline LDF & 14 & 0.65 & 19.82 \\
\hline $\mathrm{LDF}+$ oil & 14 & 5.28 & 14.82 \\
\hline \multirow[t]{2}{*}{ Oil } & 7 & 0.75 & 16.61 \\
\hline & 14 & 1.78 & 15.10 \\
\hline \multirow[t]{2}{*}{ Neemix } & 7 & 5.12 & 14.73 \\
\hline & 14 & 0.92 & 19.48 \\
\hline Control & 7 & 1.15 & 18.16 \\
\hline \multicolumn{4}{|l|}{ Orthogonal contrasts ${ }^{y}$} \\
\hline ATI vs. control & & 0.55 & 0.40 \\
\hline LDF vs. control & & 0.18 & 0.13 \\
\hline Oil vs. control & & 0.96 & 0.45 \\
\hline Neemix vs. control & & 0.38 & 0.73 \\
\hline ATI vs. LDF & & 0.18 & 0.29 \\
\hline ATI weekly vs. ATI biweekly & & 0.00 & 0.32 \\
\hline LDF weekly vs. LDF biweekly & & 0.00 & 0.00 \\
\hline Oil weekly vs oil biweekly & & 0.67 & 0.67 \\
\hline ATI vs. ATI + oil & & 0.00 & 0.02 \\
\hline LDF vs. LDF + oil & & 0.00 & 0.03 \\
\hline ATI vs. Neemix & & 0.72 & 0.51 \\
\hline LDF vs. Neemix & & 0.58 & 0.90 \\
\hline
\end{tabular}

${ }^{2}$ Experiment was planted on 2 Sept. 1994. Means were pooled across all sampling times.

${ }^{y}$ Orthogonal contrast comparisons are significant if $P \leq 0.05$.

$\mathrm{N}$-[(methylcarbamoyl)oxy]thioacetimidate $\}$; $\mathrm{O}, \mathrm{S}$-dimethyl phosphoramidothioate; and $\mathrm{Ba}$ cillus thuringiensis var. kurstaki (Magaro and Edelson, 1990; Shelton and Wyman; 1992). Unlike synthetic insecticides, neem-based insecticides are considered safe to beneficial organisms (Schmutterer, 1990). ATI appears useful for the development of IPM strategies. As progress in commercialization of neem formulations intensifies, further field studies addressing ATI dose and time dependency, application pressures and technologies, quantification of neem's impact on predators and parasitoids, and testing neem seed formulations containing mixtures of oils and compounds are needed.

\section{Literature Cited}

Ascher, K.R.S. 1993. Nonconventional insecticidal effects of pesticides available from the neem tree, Azadirachta indica. Arch. Insect Biochem. Physiol. 22:433-449.

Butterworth, J.H. and E.D. Morgan. 1968. Isolation of a substance that suppresses feeding in locusts. J. Chem. Soc. Chem. Commun. p. 23-24.

Cartwright, B., J.V. Edelson, and C. Chambers. 1987. Composite action thresholds for the control for lepidopterous pests on fresh-market cabbage in the lower Rio Grande Valley of Texas. J. Econ. Entomol. 80:175-181.

Flint, H.M. and N.J. Parks. 1989. Effect of azadirachtin from the neem tree on immature sweetpotato whitefly, Bemisia tabaci (Homoptera:Aleyrodidae) and other selected pest species on cotton. J. Agr. Entomol. 6:211-215.

Johnson, W.T. 1985. Horticultural oils. J. Environ. Hort. 3:188-191.

Kaethner, M. 1991. Keine Nebenwirkungen von Niempräparaten auf die aphidophagen Nützlinge Chrysoperla carnea und Coccinella septempunctata. Anz. Schädlingskde., Pflanzenschutz, Umweltschutz 64:97-99.

Magaro, J.J. and J.V. Edelson. 1990. Diamondback moth (Lepidoptera: Plutellidae) in south Texas: A technique for resistance monitoring in the field. J. Econ. Entomol. 83:1201-1206.

Mordue (Luntz), A.J. and A. Blackwell. 1993. Azadirachtin: An update. J. Insect Physiol. 39:903-924.

Price, J.F., D.J. Schuster, and P.M. McClain. 1990. Azadirachtin from neem tree (Azadirachta indica A. Juss.) seeds for management of sweetpotato whitefly [Bemisia tabaci (Gennadius)] on ornamentals. Proc. Fla. State Hort. Soc. 103:186-188.

Rembold, H. 1989. Isomeric azadirachtins and their mode of action, p. 47-67. In: M. Jacobson (ed.). Focus on biochemical pesticides. vol I. The neem tree. CRC Press, Boca Raton, Fla.

Schmutterer, H. 1990. Properties and potential of natural pesticides from the neem tree. Annu. Rev. Entomol. 35:271-298.

Shelton, A.M. and J.A. Wyman. 1992. Insecticide resistance for diamondback moth in North America, p. 447-454. In: N.S. Talekar (ed.). Diamondback moth and other crucifer pests. Proc. 2nd Intl. Wkshp., Tainan, Taiwan, 10-14 Dec. 1990. Asian Veg. Res. and Dev. Ctr. Publ. 92-368.

Stokes, J.B. and R.E. Redfern. 1982. Effect of sunlight on azadirachtin: Antifeeding potency. J. Environ. Sci. Health 17:57-65. 